\title{
ENHANCEMENT OF IN VITRO ANTIOXIDANT POTENTIAL OF TERMINALIA CHEBULA BY VARIOUS FRUIT EXTRACTS AND OPTIMIZATION OF CONCENTRATION BY RESPONSE SURFACE METHODOLOGY
}

\author{
GEETIKA SHARMA, VIPASHA SHARMA, TULIKA MISHRA*
}

Department of Biotechnology, University Institute of Biotechnology, Chandigarh University, Gharuan, Mohali - 140 413, Punjab, India. Email: geetikabiotech.cgc@gmail.com

Received: 09 March 2018, Revised and Accepted: 06 April 2018

\section{ABSTRACT}

Objective: The main objective of this study was to determine the enhancement of in vitro antioxidant potential of fruits of Terminalia chebula (TC) when used in combination with fruit extracts of Phyllanthus emblica, Ananas comosus, and Punica granatum. Hydroxyl $(\mathrm{OH})$ radical scavenging and 2,2-diphenyl-1-picrylhydrazyl (DPPH) free radical scavenging assays were used to analyze the antioxidant potential.

Method: Formulations of different combinatorial concentrations of fruits to prepare a mixture were achieved with central composite design through response surface methodology. Screening of 300 different combinations of various concentrations was done through hydroxyl radical scavenging assay followed by statistical analysis of data. Further validation of results was done by measuring the antioxidant potential of most bioactive extracts by DPPH method.

Results: Screening of 300 samples of different combinations for antioxidant potential revealed the samples with highest percentage inhibition in aqueous (85.2\%), ethanolic (92.9\%), and aqueous-ethanolic (84.21\%) extracts. Data were subjected to analysis of variance and generated a threedimensional response surface plot for highest activity. Further subjecting these extracts to DPPH assay revealed a significant enhancement in the antioxidant potential of ethanolic extract of TC when used in mixture with other plants.

Conclusion: Antioxidant activity of TC was enhanced when used in combination with other fruits extracts. These synergistic studies generating valuable interactions between various phytochemicals could lead to a momentous increase in other associated activities to fight against diseases such as cancer and cardiovascular disorders. Further research on isolation of bioactive compounds in the mixture and their potential to fight various types of cancer could lead to a significant augmentation in the activity of natural compounds.

Keywords: Terminalia chebula, Response surface methodology, Central composite design, 2,2-diphenyl-1-picrylhydrazyl, Antioxidant potential.

(c) 2018 The Authors. Published by Innovare Academic Sciences Pvt Ltd. This is an open access article under the CC BY license (http://creativecommons. org/licenses/by/4. 0/) DOI: http://dx.doi.org/10.22159/ajpcr.2018.v11i7.25786

\section{INTRODUCTION}

Plants and their products are the nature's gift to humans and animals that help them to flourish by leading a disease free healthy life. Since thousands of years, plants are playing important role in maintaining human health and quality of life. The various native systems such as Siddha, Ayurveda, Unani, and Allopathy use numerous plant species to treat different ailments [1]. Medicinal plants have been used for centuries as remedies for human diseases owing to the presence of certain components of therapeutic value. The restorative properties of medicinal plants are attributable to the presence of various bioactive phytochemicals which may enlighten their conventional uses against various ailments [2].

The increased consumption of natural antioxidants present in fruits and vegetables boosts up the antioxidant capacity of plasma, and these constituents are reported to mitigate the damage caused by the oxidative stress [3-5]. As revealed by the latest studies, the defensive effect of fruits and vegetables is at least partially attributable to the phytochemicals present in them [6-8]. The additive and synergistic effects of phytochemicals in fruits and vegetables have been proposed to be responsible for their potent antioxidant and anticancer potentials. The benefit of a diet rich in fruits and vegetables is credited to the complex mixture of phytochemicals present in these and other whole foods [9-11].

To protect the cells and organ systems of the body against reactive oxygen species, humans have evolved a highly sophisticated and complex antioxidant protection system that functions interactively and synergistically to neutralize free radicals. Under natural conditions, a dynamic balance between the free radicals and antioxidants is maintained. The amount of antioxidant principles present under normal physiological conditions may be insufficient to neutralize free radicals generated. Therefore, antioxidants can be given from external sources like food, etc., to protect against harmful diseases and to prevent, delay, or ameliorate many of these disorders [12].

The present research has been designed to study the synergistic effect of a common herb, Terminalia chebula (TC) over the antioxidant potential of various fruit extracts. TC belongs to the family Combretaceae and is found throughout India, especially in deciduous forestsand areas oflightrainfall [13]. In Tibet, due to its astonishing wound healing property, it is entitled as "the king of medicines". So far, literature shows that TC have potential biological and pharmacological properties including antibacterial, antimutagenic, antiviral, antifungal, adaptogenic, anti-anaphylactic, hypocholesterolemic, gastrointestinal motility improving, anti-ulcerogenic, hepatoprotective, cardioprotective, radioprotective, antidiabetic, retinoprotective, purgative, wound healing, antispasmodic, immunomodulatory, and chemopreventive potential [14]. From the above properties of plant, it can be speculated that when it will be used in combination with other fruit extracts, it will enhance the antioxidant and anticancer potential of the extract to a greater extent and this mixture could be a potent anticarcinogenic agent.

\section{METHODS}

Chemicals and reagents

2,2-diphenyl-1-picrylhydrazyl (DPPH), thiobarbituric acid (TBA), trichloroacetic acid (TCA), ascorbic acid, and ethylenediaminetetraacetic 
acid (EDTA) were purchased from Sigma-Aldrich, USA, whereas hydrogen peroxide and 2-deoxyribose were procured from HiMedia Lab Ltd., Mumbai, India. Distilled deionized water was prepared by Camco Industries, Chandigarh (India).

\section{Plant sample collection and authentication}

Phyllanthus emblica (PE), Ananas comosus (AC), Punica granatum $(\mathrm{PG})$, and $\mathrm{TC}$ used in the present investigation were procured from local market of Chandigarh, India. Botanical identification of abovementioned samples was done at Botany Department, Punjab University, Chandigarh. The deposition of voucher specimens in herbarium was done with accession number 21126, 21127, 21128, and 21129 for TC, $\mathrm{PG}, \mathrm{AC}$, and PE, respectively.

\section{Extract preparation}

Aqueous, ethanolic, and aqueous-ethanolic (1:1) extracts of fruits of TC, PG, AC, and PE were prepared by the method described by Chintalapani et al., 2018, by doing slight modifications as discussed ahead [15]. Fruits were dried at $40^{\circ}$ for 3-4 days and powdered. Extract preparation of four samples was achieved by overnight soaking the dried powder in a respective solvent with a ratio of $1: 10(\mathrm{w} / \mathrm{v})$ subjected to intermittent shaking. Furthermore, extracts were subjected to evaporation under reduced pressure in a rotary evaporator at $40^{\circ} \mathrm{C}$ and stored at $4^{\circ} \mathrm{C}$ for further analysis.

Optimization of sample concentrations using response surface methodology (RSM)

In the present experimental set, central composite design (CCD) was explored for making various combinations of different concentration of three fruit extracts, whereas the concentrations of TC $(50,100,200$, 400 , and $500 \mu \mathrm{g} / \mathrm{ml}$ ) were fixed for each set. The independent variables were PE: $50-300 \mu \mathrm{g} / \mathrm{ml}$, AC: $50-200 \mu \mathrm{g} / \mathrm{ml}$, and PG: $20-200 \mu \mathrm{g} / \mathrm{ml}$. The subjection of above-mentioned concentration range of independent variables in CCD generated 20 combinations by design expert software for analysis of antioxidant potential with respect to selected concentrations of TC for each set.

\section{In vitro antioxidant assay}

\section{Hydroxyl radical $(\mathrm{OH})$ scavenging activity}

Deoxyribose assay was used to determine the ability of extract to scavenge the hydroxyl radical generated from $\mathrm{Fe}^{+}$/Ascorbate/EDTA/ $\mathrm{H}_{2} \mathrm{O}_{2}$ system in aqueous medium. Reaction mixture containing $3.0 \mathrm{mM}$ deoxyribose $(100 \mu \mathrm{l}), 0.1 \mathrm{mM} \mathrm{FeCl}_{3}(200 \mu \mathrm{l}), 0.1 \mathrm{mM}$ EDTA $(200 \mu \mathrm{l}), 0.1$
$\mathrm{mM}$ ascorbic acid $(100 \mu \mathrm{l}), 1 \mathrm{mM}$ hydrogen peroxide $\left(\mathrm{H}_{2} \mathrm{O}_{2}\right)(100 \mu \mathrm{l})$, and $20 \mathrm{mM}$ phosphate buffer ( $\mathrm{pH}$ 7.4) was subjected to 20 different combinatorial concentrations of extracts $(500 \mu \mathrm{l})$ as generated by RSM. This assay was run in five sets, each set having a fixed concentration of TC, 50,100,200,400, and $500 \mu \mathrm{g} / \mathrm{ml}$.

Followed by an incubation of $1 \mathrm{~h}$ at $37^{\circ} \mathrm{C}$, the amount of TBA -reactive substance formed due to the attack of hydroxyl radicals on the deoxyribose was measured as per the method described by Ohkawa et al. [16]. Thereafter, $1 \mathrm{ml}$ of TBA, $1 \%$ and $1 \mathrm{ml}$ of TCA, $2.8 \%$ were added in the reaction mixture followed by incubation at $100^{\circ} \mathrm{C}$ for $20 \mathrm{~min}$. L-ascorbic acid was employed as standard reference. The pink color thus formed in reaction mixture was measured at $532 \mathrm{~nm}$ against a blank containing deoxyribose and buffer. The percentage inhibition was calculated by the following equation:

Inhibition of lipid peroxidation $(\%)=\left(\mathrm{A}_{\text {control }}-\mathrm{A}_{\text {sample }}\right) / \mathrm{A}_{\text {control }} \times 100$

\section{DPPH radical scavenging assay}

The screened combinations were subjected to DPPH free radical scavenging activity according to slight modifications in the protocol [17]. Briefly, $3.5 \mathrm{ml}$ methanolic solution of $0.5 \mathrm{mM}$ DPPH was added to $80 \mu \mathrm{l}$ of various combinatorial concentrations of plant extract followed by incubation at $37^{\circ} \mathrm{C}$ for $20 \mathrm{~min}$ in the dark. Methanol was used as a blank. However, antioxidant activity of L-ascorbic acid as standard reference was also assayed. The scavenging activity of the extract was estimated by the following equation, where A denotes absorbance:

$\%$ inhibition $=\left(\mathrm{A}_{\text {control }}-\mathrm{A}_{\text {sample }}\right) / \mathrm{A}_{\text {control }} \times 100$

The inhibitory concentration $\left(\mathrm{IC}_{50}\right)$ values were calculated using the dose inhibition curve in linear range by plotting the extract concentration versus the corresponding scavenging effect in terms of $\%$ inhibition.

\section{RESULTS AND DISCUSSION}

\section{Response for optimization}

Improving the process conditions for the achievement of a desired product with high yield, low production costs, and low use of energy requires the use of suitable optimization procedures. RSM software generated 20 different combinations of various concentrations with respect to $\mathrm{PE}, \mathrm{AC}$, and $\mathrm{PG}$ fruit extracts as represented in Table 1. These 20 combinations were studied to impose an enhancing effect on the in vitro antioxidant potential of TC. Each selected concentration of TC $(50,100,200,400$, and

Table 1: The 20 different combinations generated by RSM. Factors 1, 2, and 3 correspond to the different concentrations of PE, AC, and $\mathrm{PG}$, respectively. Run represents combination number from C1 to C20

\begin{tabular}{llll}
\hline Run & Factor $\mathbf{1}$ A:P. emblica microgram/ml & Factor $\mathbf{2}$ B:A. comosus microgram/ml & Factor $\mathbf{3}$ C:P. granatum microgram/ml \\
\hline 1 & 50 & 200 & 20 \\
2 & 175 & 251.134 & 110 \\
3 & 175 & 125 & 110 \\
4 & 175 & 125 & 110 \\
5 & 175 & 125 & 110 \\
6 & 50 & 50 & 20 \\
7 & 300 & 200 & 200 \\
8 & 175 & 125 & 110 \\
9 & 50 & 200 & 200 \\
10 & 385.224 & 125 & 110 \\
11 & 50 & 50 & 200 \\
12 & 175 & 125 & 41.3614 \\
13 & 300 & 50 & 20 \\
14 & 175 & 125 & 110 \\
15 & 175 & 125 & 261.361 \\
16 & 35.2241 & 125 & 110 \\
17 & 175 & 125 & 110 \\
18 & 175 & 1.13445 & 110 \\
19 & 300 & 200 & 20 \\
20 & 300 & 50 & 200 \\
\hline
\end{tabular}

RSM: Response surface methodology, PE: Phyllanthus emblica, AC: Ananas comosus, PG: Punica granatum 
$500 \mu \mathrm{g} / \mathrm{ml}$ ) was assayed individually with 20 combinations generated by RSM. Response for the optimization of concentration was analyzed in terms of percentage inhibition of lipid peroxidation. Similar studies were done by the use of CCD to study the effect of pectinase concentration, cellulase concentration, hemicellulase concentration, temperature, and incubation time on the stevioside extraction from Stevia rebaudiana leaves. The authors tested 26 experimental conditions and optimized them using graphical and numerical approaches [18].

\section{Hydroxyl radical $(\mathrm{OH})$ scavenging assay}

Quantification of hydroxyl radical scavenging activity of 20 different combinations was achieved by measuring the inhibition of the degradation of 2-deoxyribose by the free radicals produced by the Fenton reaction. All combinations revealed a wide variation in the antioxidant potential for aqueous, ethanolic, and aqueous-ethanolic extracts. Whereas, the highest response in enhancing the antioxidant potential of TC was shown by combination number 15 of ethanolic extract (92.9\%) containing PE, AC, PG, and TC in 175, 125, 261.3, and $400 \mu \mathrm{g} / \mathrm{ml}$ concentration, respectively, followed by combination number 10 for aqueous (85.2\%) containing TC $400 \mu \mathrm{g} / \mathrm{ml}$ and combination number 16 for aqueous-ethanolic extracts (84.21\%) containing TC $500 \mu \mathrm{g} / \mathrm{ml}$. The hydroxyl radical has the capacity to break DNA strands contributing to carcinogenesis, mutagenesis, and cytotoxicity. Moreover, it is considered one of the quick initiators of lipid peroxidation process [19]. Tables 2-4 represent the complete result of hydroxyl $(\mathrm{OH})$ radical scavenging assay for all the five concentrations of TC: 50,100, 200, 400, and $500 \mu \mathrm{g} / \mathrm{ml}$ with respect to aqueous, ethanolic, and aqueous-ethanolic extracts.

\section{Statistical analysis of data}

Hydroxyl radical scavenging assay was performed on a total of 300 different combinatorial concentrations, 100 each of aqueous, ethanolic, and aqueous-ethanolic extracts. Results were calculated in terms of percentage inhibition of hydroxyl radical by various concentrations of extracts, and highest value of percent inhibition corresponds to ethanolic combination number 15 (92.98\%) with the concentration of TC being $400 \mu \mathrm{g} / \mathrm{ml}$. Statistical significance of model that generated values of combination 1-20 (Table 1) for ethanolic extract containing TC $400 \mu \mathrm{g} / \mathrm{ml}$ was checked by F-test analysis of variance as represented in Table 5 . The Model F-value of 3.42 implies that the model is significant. $p<0.0500$ indicates that the model terms are statistically significant. The lack of fit
F-value of 3.43 implies that the lack of fit is not significant relative to the pure error. This is in agreement with a study in which RSM was employed to optimize the conditions for antioxidant potential and polyphenols from apricot powder (Prunus armeniaca L.) using four independent variables: Methanol $(20 \%, 35 \%, 50 \%, 65 \%$, and $80 \%)$, solvent/sample ratio $(10$, $15,20,25$, and 30$)$, temperature $\left(20,30,40,50\right.$, and $\left.60^{\circ} \mathrm{C}\right)$, and time (20, $30,40,50$, and $60 \mathrm{~min}$ ). The results showed that antioxidant potential and total polyphenols in the experiments varied from $76.15 \%$ to $96.68 \%$ and 8.77 to $12.11 \mathrm{mg} \mathrm{GAE} / \mathrm{g}$, respectively. The F-values for antioxidant potential and total polyphenols were 0.99 and 4.44 , respectively [20]. The validation of the results of analyzed data in the present investigation can be drawn from three-dimensional response surface plot generated by design expert software (Trial Version 11), Stat Ease Inc., USA, as shown in Fig. 1. The graph is plotted between various concentrations of ethanolic extracts in combinatorial concentrations and percentage scavenging of $\mathrm{OH}$ radicals. The values from the graph represent that the $\mathrm{OH}$ radical scavenging by the various combinations of extracts is not dependent on the increasing or decreasing concentrations of extracts.

\section{DPPH radical scavenging assay}

Extensive use of DPPH radical scavenging activity has been observed for screening antioxidants from fruit juices or extracts [21]. In a study done to understand synergetic antioxidant effect of several common natural pigments among the gardenia yellow, black bean red, and sorghum red, synergetic effect and optimal formulation of compound antioxidant were determined with the RSM. The total scavenging rate was $66.78 \%$, and it was less than the combined formula slightly. It showed that combined formula antioxidant activity was better than single antioxidant and consistent with the regression model analysis [22]. In another study, the antioxidant activity of whole plant extracts of Sesuvium portulacastrum L. was checked by DPPH assay in which diethyl ether extract showed the highest total phenolic content and antioxidant potential among all the extracts of $S$. portulacastrum [15]. In the present study, the results of DPPH radical scavenging activity of ethanolic extract combination number 15 increased with increase in concentration representing a dose-dependent curve as shown in Figs. 2-4. The antioxidant and radical scavenging properties of plants are based on their medicinal value. Results in this study coincide with the results of ethanolic extracts of Tribulus terrestris fruits (TTFs) and Mesua ferrea flower (MFF), both of which exerted a significant

Table 2: Percentage inhibition of hydroxyl radical by phytochemicals present in the aqueous extract of PE, AC, PG, and various concentrations of TC. The aqueous combination number 10 with $\mathrm{TC}=400 \mu \mathrm{g} / \mathrm{ml}$ showed the highest percentage inhibition of $\mathrm{OH}$ radical $(85.25 \%)$

\begin{tabular}{|c|c|c|c|c|c|}
\hline \multicolumn{6}{|c|}{ Hydroxyl radical $(\mathrm{OH})$ scavenging assay of aqueous extract } \\
\hline Combination number & $\begin{array}{l}\% \text { inhibition with } \\
\text { TC }(50 \mu \mathrm{g} / \mathrm{ml})\end{array}$ & $\begin{array}{l}\text { \% inhibition with TC } \\
(100 \mu \mathrm{g} / \mathrm{ml})\end{array}$ & $\begin{array}{l}\% \text { inhibition with } \\
\text { TC }(200 \mu \mathrm{g} / \mathrm{ml})\end{array}$ & $\begin{array}{l}\% \text { inhibition with } \\
\text { TC }(400 \mu \mathrm{g} / \mathrm{ml})\end{array}$ & $\begin{array}{l}\% \text { inhibition with } \\
\mathrm{TC}(500 \mu \mathrm{g} / \mathrm{ml})\end{array}$ \\
\hline 1 & 68.31 & 61.75 & 69.95 & 78.69 & 80.33 \\
\hline 2 & 74.32 & 65.03 & 73.77 & 76.50 & 81.97 \\
\hline 3 & 61.75 & 62.30 & 78.14 & 83.61 & 77.60 \\
\hline 4 & 64.48 & 68.85 & 75.41 & 78.14 & 84.70 \\
\hline 5 & 66.67 & 61.75 & 68.85 & 79.78 & 81.97 \\
\hline 6 & 61.20 & 56.28 & 74.86 & 84.15 & 79.23 \\
\hline 7 & 62.30 & 63.93 & 71.04 & 70.49 & 77.60 \\
\hline 8 & 63.39 & 71.04 & 67.21 & 72.68 & 75.96 \\
\hline 9 & 54.10 & 62.30 & 68.31 & 70.49 & 75.96 \\
\hline 10 & 60.66 & 63.93 & 76.50 & 85.25 & 79.23 \\
\hline 11 & 58.47 & 63.39 & 75.96 & 73.22 & 77.05 \\
\hline 12 & 69.95 & 63.39 & 76.50 & 74.86 & 83.06 \\
\hline 13 & 72.68 & 67.21 & 78.69 & 82.51 & 73.22 \\
\hline 14 & 63.39 & 63.39 & 78.14 & 75.96 & 74.86 \\
\hline 15 & 65.57 & 72.68 & 77.60 & 76.50 & 74.32 \\
\hline 16 & 51.91 & 80.33 & 80.33 & 68.31 & 69.95 \\
\hline 17 & 66.12 & 70.49 & 78.69 & 71.58 & 81.42 \\
\hline 18 & 67.21 & 69.40 & 76.50 & 76.50 & 79.78 \\
\hline 19 & 69.40 & 70.49 & 78.14 & 79.78 & 73.77 \\
\hline 20 & 73.22 & 71.58 & 79.23 & 81.97 & 78.69 \\
\hline
\end{tabular}

PE: Phyllanthus emblica, AC: Ananas comosus, PG: Punica granatum, TC: Terminalia chebula 
Table 3: Percentage inhibition of hydroxyl radical by phytochemicals present in the ethanolic extract of PE, AC, PG, and various concentrations of TC. The ethanolic combination number 15 with $\mathrm{TC}=400 \mu \mathrm{g} / \mathrm{ml}$ showed the highest percentage inhibition of $\mathrm{OH}$ radical $(92.98 \%)$

\begin{tabular}{|c|c|c|c|c|c|}
\hline \multicolumn{6}{|c|}{ Hydroxyl radical $(\mathrm{OH})$ scavenging assay of ethanolic extract } \\
\hline Combination number & $\begin{array}{l}\% \text { inhibition with } \\
\text { TC }(50 \mu \mathrm{g} / \mathrm{ml})\end{array}$ & $\begin{array}{l}\% \text { inhibition with } \\
\text { TC }(100 \mu \mathrm{g} / \mathrm{ml})\end{array}$ & $\begin{array}{l}\% \text { inhibition with } \\
\text { TC }(200 \mu \mathrm{g} / \mathrm{ml})\end{array}$ & $\begin{array}{l}\% \text { inhibition with } \\
\text { TC }(400 \mu \mathrm{g} / \mathrm{ml})\end{array}$ & $\begin{array}{l}\% \text { inhibition with } \\
\text { TC }(500 \mu \mathrm{g} / \mathrm{ml})\end{array}$ \\
\hline 2 & 77.78 & 76.61 & 79.53 & 75.44 & 85.96 \\
\hline 3 & 73.68 & 82.46 & 77.78 & 67.84 & 79.53 \\
\hline 4 & 79.53 & 78.36 & 75.44 & 64.91 & 73.68 \\
\hline 5 & 75.44 & 80.12 & 81.87 & 70.18 & 72.51 \\
\hline 6 & 77.78 & 84.21 & 83.04 & 60.23 & 83.63 \\
\hline 7 & 72.51 & 70.76 & 71.35 & 61.40 & 80.70 \\
\hline 8 & 55.56 & 72.51 & 75.44 & 63.16 & 83.04 \\
\hline 9 & 61.99 & 70.76 & 85.38 & 55.56 & 84.21 \\
\hline 10 & 66.67 & 84.21 & 80.70 & 60.82 & 82.46 \\
\hline 11 & 71.35 & 73.68 & 72.51 & 60.23 & 76.02 \\
\hline 12 & 50.88 & 74.86 & 77.78 & 67.25 & 77.78 \\
\hline 13 & 81.29 & 81.87 & 80.12 & 80.12 & 81.87 \\
\hline 14 & 61.40 & 75.44 & 71.93 & 61.99 & 83.63 \\
\hline 16 & 77.19 & 68.42 & 74.27 & 51.46 & 75.44 \\
\hline 17 & 81.87 & 71.93 & 78.36 & 58.48 & 77.19 \\
\hline 18 & 71.93 & 76.02 & 76.61 & 66.08 & 80.70 \\
\hline 19 & 60.23 & 79.78 & 78.36 & 67.25 & 77.78 \\
\hline 20 & 69.59 & 80.70 & 83.04 & 71.35 & 79.53 \\
\hline
\end{tabular}

PE: Phyllanthus emblica, AC: Ananas comosus, PG: Punica granatum, TC: Terminalia chebula

Table 4: Percentage inhibition of hydroxyl radical by phytochemicals present in the aqueous-ethanolic extract of PE, AC, PG ,and various concentrations of TC. The aqueous-ethanolic combination number 16 with $\mathrm{TC}=500 \mu \mathrm{g} / \mathrm{ml}$ showed the highest percentage inhibition of $0 H$ radical $(84.21 \%)$

\begin{tabular}{|c|c|c|c|c|c|}
\hline \multicolumn{6}{|c|}{ Hydroxyl $(\mathrm{OH})$ radical scavenging assay of aqueous-ethanolic extract } \\
\hline Combination number & $\begin{array}{l}\% \text { inhibition with } \\
\text { TC }(50 \mu \mathrm{g} / \mathrm{ml})\end{array}$ & $\begin{array}{l}\% \text { inhibition with } \\
\text { TC }(100 \mu \mathrm{g} / \mathrm{ml})\end{array}$ & $\begin{array}{l}\% \text { inhibition with } \\
\text { TC }(200 \mu \mathrm{g} / \mathrm{ml})\end{array}$ & $\begin{array}{l}\% \text { inhibition with } \\
\text { TC }(400 \mu \mathrm{g} / \mathrm{ml})\end{array}$ & $\begin{array}{l}\% \text { inhibition with } \\
\text { TC }(500 \mu \mathrm{g} / \mathrm{ml})\end{array}$ \\
\hline 2 & 77.19 & 66.67 & 65.79 & 33.33 & 76.32 \\
\hline 3 & 77.19 & 78.07 & 64.04 & 32.46 & 74.56 \\
\hline 4 & 78.07 & 31.58 & 60.53 & 39.47 & 76.32 \\
\hline 5 & 50.00 & 42.98 & 57.89 & 38.60 & 49.12 \\
\hline 6 & 70.18 & 52.63 & 66.67 & 48.25 & 69.30 \\
\hline 7 & 81.58 & 54.39 & 70.18 & 40.35 & 80.70 \\
\hline 8 & 70.18 & 42.98 & 52.63 & 43.86 & 71.05 \\
\hline 9 & 56.14 & 39.47 & 16.67 & 55.26 & 57.89 \\
\hline 10 & 66.67 & 37.72 & 61.40 & 40.35 & 67.54 \\
\hline 11 & 50.00 & 57.02 & 53.51 & 48.25 & 51.75 \\
\hline 12 & 33.33 & 41.23 & 57.89 & 41.23 & 33.33 \\
\hline 13 & 25.44 & 35.96 & 50.00 & 39.47 & 25.44 \\
\hline 14 & 70.18 & 21.93 & 57.02 & 38.60 & 70.18 \\
\hline 16 & 81.58 & 14.91 & 43.86 & 44.74 & 84.21 \\
\hline 17 & 70.18 & 20.18 & 50.00 & 38.60 & 68.42 \\
\hline 18 & 3.51 & 56.14 & 56.14 & 48.25 & 4.39 \\
\hline 19 & 70.18 & 23.68 & 57.02 & 44.74 & 69.30 \\
\hline 20 & 45.61 & 14.91 & 55.26 & 45.61 & 48.25 \\
\hline
\end{tabular}

PE: Phyllanthus emblica, AC: Ananas comosus, PG: Punica granatum, TC: Terminalia chebula

scavenging activity on the DPPH radical which was found to be increasing with the increasing concentration and thus revealed dosedependent curves. At $250 \mu \mathrm{g} / \mathrm{ml}$ concentration, the exerted values of MFF and TTF extracts were found to be $54.96 \%$ (with $\mathrm{IC}_{50} 131.0 \mu \mathrm{g} /$ $\mathrm{ml}$ ) and $51.46 \%$ (with $\mathrm{IC}_{50} 142.27 \mu \mathrm{g} / \mathrm{ml}$ ), respectively, when compared to ascorbic acid, the standard (86.10\%) [23]. Whereas, in the present study the highest activity was found in ethanolic extract, followed by aqueous and aqueous-ethanolic extract. The DPPH scavenging activity of TC was enhanced from $72.36 \%$ to $87.37 \%$ when used in combination with other extracts. The $\mathrm{IC}_{50} \mathrm{DPPH}$ values for ascorbic acid, aqueous, ethanolic, aqueous-ethanolic, and TC extracts were obtained from the linear regression equation from respective graphs as represented in Table 6.

A significant enhancement in the antioxidant potential of TC when used in a mixture with other extracts is supported by the study which states that several plant preparations such as a mixture of aqueous extracts of Spilanthes Africana, Portulaca oleracea, and Sida rhombifolia are currently utilized in Foumban (West Cameroon) to manage diabetes that was induced to rats by intraperitoneal injection of streptozotocin at a dose of $50 \mathrm{mg} / \mathrm{kg} \mathrm{b.w}$. Each extract and the mixture demonstrated a significant scavenging property on $\mathrm{DPPH}$ and $\mathrm{OH}$ radicals and revealed 
Table 5: The ANOVA for quadratic model for percentage inhibition of $\mathrm{OH}$ radical (generated by design expert, RSM). The $\mathrm{p}$ value of the lack of fit value was of 0.1013 (not significant), the model was of 0.0342 (significant), which showed that the model fit the RSM data significantly

\begin{tabular}{llllll}
\hline Source & Sum of square? & df & Mean & F-value & p \\
\hline Model & 1197.73 & 9 & 133.08 & 3.42 & 0.0342 \\
A-P. emblica & 343.86 & 1 & 343.86 & 0.84 & 0.0140 \\
B-A. comosus & 1.83 & 1 & 1.83 & 0.0471 & 0.8325 \\
C-P. granatum & 22.90 & 1 & 22.90 & 0.5890 & 0.4605 \\
AB & 79.04 & 1 & 79.04 & 0.03 & 0.1844 \\
AC & 1.07 & 1 & 1.07 & 02474 & 0.8716 \\
BC & 9.62 & 1 & 9.62 & 10.09 & 0.6297 \\
A $^{2}$ & 392.20 & 1 & 392.20 & 0.5410 & 0.0099 \\
$B^{2}$ & 21.03 & 1 & 21.03 & & 0.4789 \\
C $^{2}$ & 618.78 & 1 & 618.78 & 3.43 & 0.0026 \\
Residual & 388.80 & 10 & 38.88 & & 0.1013 \\
Lack of fit & 300.97 & 5 & 60.19 & & Not significant \\
Pure error & 87.83 & 5 & 17.57 & & \\
Cor total & 1586.54 & 19 & & & \\
\hline
\end{tabular}

RSM: Response surface methodology, ANOVA: Analysis of variance

Table 6: The results of DPPH assay for concentrations ranging from 5, 10, 15, and $20 \mu \mathrm{g} / \mathrm{ml}$ for ascorbic acid, aqueous, ethanolic, aqueous-ethanolic, and TC extracts. Comparison of IC $_{50}$ values and percentage inhibition of DPPH radical by TC and various combinatorial extracts. $\mathrm{C10}, \mathrm{C15}$, and $\mathrm{C} 16$ represent combinations with concentration of TC being 400, 400, and $500 \mu \mathrm{g} / \mathrm{ml}$, respectively. Values are mean of three replicates $\pm S D$

\begin{tabular}{|c|c|c|c|c|c|}
\hline \multirow{2}{*}{$\begin{array}{l}\text { Sample concentration } \\
(\mu \mathrm{g} / \mathrm{ml})\end{array}$} & \multicolumn{5}{|c|}{ DPPH free radical scavenging activity (\%) } \\
\hline & Ascorbic acid (AA) & $\begin{array}{l}\text { Aqueous extract } \\
(\mathrm{C} 10+\mathrm{TC} 400 \\
\mu \mathrm{g} / \mathrm{ml})\end{array}$ & $\begin{array}{l}\text { Ethanolic extract } \\
(\mathrm{C} 15+\mathrm{TC} 400 \\
\mu \mathrm{g} / \mathrm{ml})\end{array}$ & $\begin{array}{l}\text { Aqueous-ethanolic } \\
(\mathrm{C} 16+\mathrm{TC} 500 \\
\mu \mathrm{g} / \mathrm{ml})\end{array}$ & TC (TC $500 \mu \mathrm{g} / \mathrm{ml})$ \\
\hline 5 & $23.59 \pm 2.95$ & $19.53 \pm 1.24$ & $27.50 \pm 1.80$ & $20.33 \pm 1.80$ & $18.45 \pm 1.84$ \\
\hline 10 & $38.25 \pm 2.19$ & $32.67 \pm 1.45$ & $41.10 \pm 2.32$ & $31.16 \pm 2.81$ & $28.32 \pm 2.34$ \\
\hline 15 & $56.73 \pm 2.51$ & $53.42 \pm 1.48$ & $64.10 \pm 1.62$ & $50.60 \pm 2.52$ & $52.64 \pm 2.15$ \\
\hline 20 & $76.73 \pm 2.45$ & $72.63 \pm 2.06$ & $87.37 \pm 1.94$ & $70.68 \pm 2.89$ & $72.36 \pm 2.25$ \\
\hline $\mathrm{IC}_{50}(\mu \mathrm{g} / \mathrm{ml})$ & 12.93 & 14.01 & 11.41 & 14.50 & 14.37 \\
\hline
\end{tabular}

SD: Standard deviation, TC: Terminalia chebula, DPPH: 2,2-diphenyl-1-picrylhydrazyl, IC $_{50}$ : inhibitory concentration

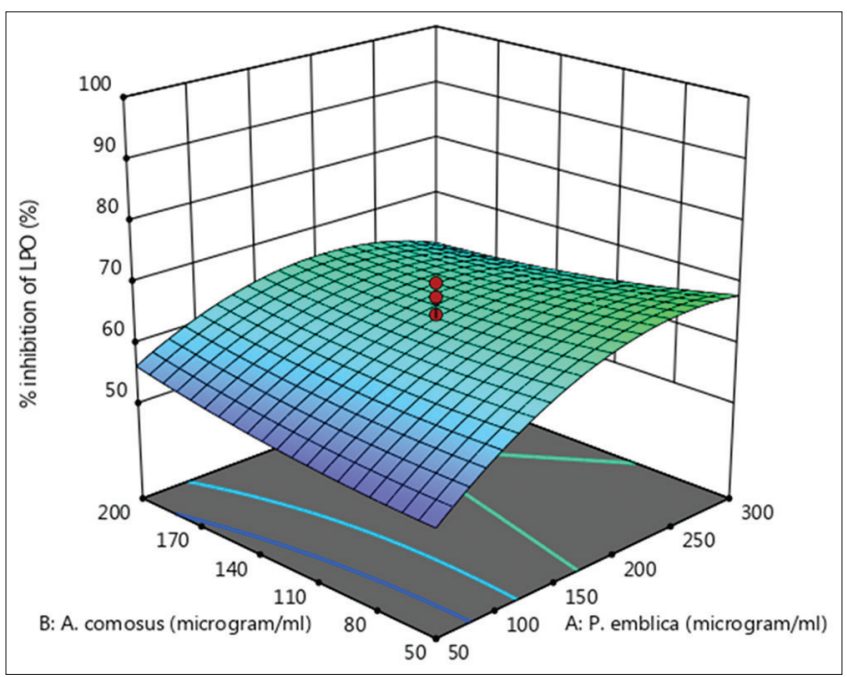

Fig. 1: Three-dimensional response surface plot for establishing the response values between the independent variables represented by $A$ and $B$ and the response called inhibition of lipid peroxidation by $\mathrm{OH}$ radical through various extracts

a good antioxidant property. Thus, it can be concluded from the study that the mixture of plant extracts had hypoglycemic, antioxidant, and hypolipidemic properties and can be used for the management of diabetes mellitus [24].

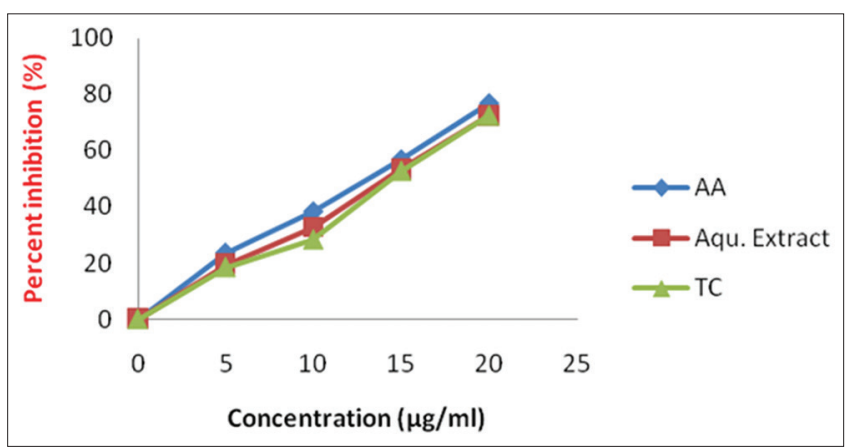

Fig. 2: Comparison of 2,2-diphenyl-1-picrylhydrazyl scavenging activity of aqueous extract combination (C10+ Terminalia chebula [TC] $400 \mu \mathrm{g} / \mathrm{ml})$, only TC $(500 \mu \mathrm{g} / \mathrm{ml})$ and ascorbic acid as standard. The IC50 value of aqueous extract of combination $\mathrm{C} 10+\mathrm{TC}=400 \mu \mathrm{g} / \mathrm{ml}$ is calculated to be $14.01 \mu \mathrm{g} / \mathrm{ml}$ with the help of linear regression equation being $y=3.582 x-0.182$ and the value of $R^{2}=0.995$

\section{CONCLUSION}

The present study indicates that a mixture of PE, AC, PG, and TC in fixed concentration exhibits a significant amount of antioxidant potential that is higher than the potential of TC alone. Generation of 300 different combinations with varying concentrations was achieved by application of CCD through RSM software. This observation highlights the importance of selecting the best combination of extract based on 


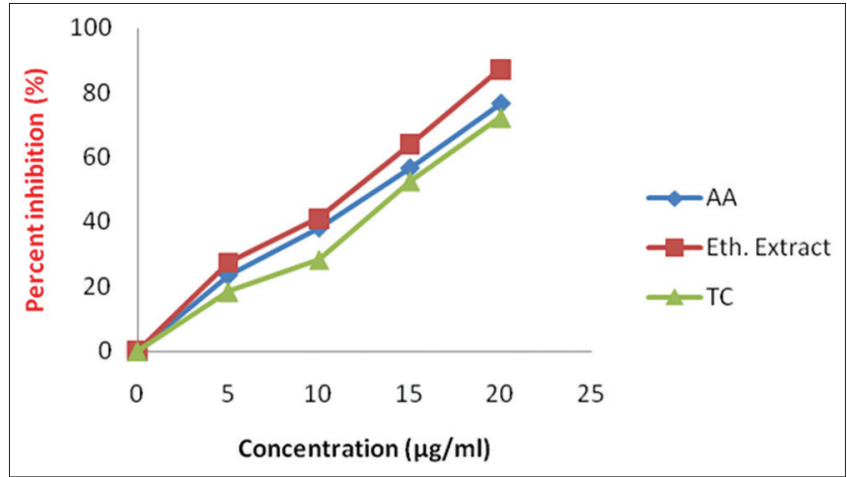

Fig. 3: Comparison of 2,2-diphenyl-1-picrylhydrazyl scavenging activity of ethanolic extract combination (C15+ Terminalia chebula [TC] $400 \mu \mathrm{g} / \mathrm{ml})$, only TC $(500 \mu \mathrm{g} / \mathrm{ml})$ and ascorbic acid as standard. The IC50 value of ethanolic extract of combination $\mathrm{C} 15+\mathrm{TC}=400 \mu \mathrm{g} / \mathrm{ml}$ is calculated to be $11.41 \mu \mathrm{g} / \mathrm{ml}$ with the help of linear regression equation being $y=4.226 x+1.744$ and the value of $R 2=0.992$

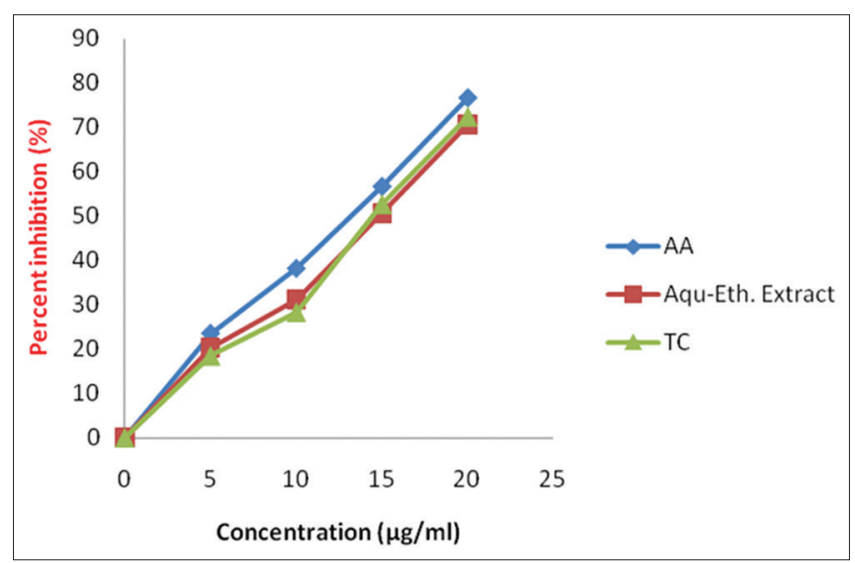

Fig. 4: Comparison of 2,2-diphenyl-1-picrylhydrazyl scavenging activity of aqueous-ethanolic extract combination (C16+ Terminalia chebula [TC] $500 \mu \mathrm{g} / \mathrm{ml})$, only TC $(500 \mu \mathrm{g} / \mathrm{ml})$ and ascorbic acid as standard. The IC50 value of aqueous-ethanolic extract of combination $\mathrm{C} 16+\mathrm{TC}=500 \mu \mathrm{g} / \mathrm{ml}$ is calculated to be $14.50 \mu \mathrm{g} / \mathrm{ml}$ with the help of linear regression equation being $y=3.432 x-0.228$ and the value of $R^{2}=0.991$

the results of hydroxyl radical scavenging assay followed by statistical analysis of generated data. The most potent bioactive combinations screened through above method were subjected to DPPH radical scavenging assay. The outcome arising from this study revealed a significant enhancement in the antioxidant potential of TC when used in a mixture. These in vitro interactions of bioactive compounds of a mixture provide interesting information on enhancing antioxidant potential by synergistic effects. However, further work on combinatorial studies of these extracts may generate an enhanced potential to cure oxidative stress-related diseases such as cancer, cardiovascular, and other chronic diseases.

\section{ACKNOWLEDGMENT}

The authors would like to express deep gratitude to Dr. Nancy George, Faculty of Biotechnology Department, Chandigarh University, for her guidance in the data interpretation through RSM Software and Mr. Jagtar Singh, Laboratory Instructor, Biotechnology, Chandigarh University, to provide support during the experimental work conducted in laboratory.

\section{AUTHOR'S CONTRIBUTION}

All the authors have equally contributed.

\section{CONFLICTS OF INTEREST}

The authors declared that they have no conflicts of interest.

\section{REFERENCES}

1. Rabe T, Staden JV. Antibacterial activity of South African plants used for medicinal purposes. J Ethnopharmacol 1997;56:81-7.

2. Sajeesha S, Nishat A. Tripathi YC. Ethnomedicinal, phytochemical and pharmacological aspects of Flacourtia jangomas: A review. Int J Pharm Pharm Sci 2018;10:9-15.

3. Lie FS, Jieh HT, Je HC, Chih YC, Chiu PL. Antioxidant properties of extracts from medicinal plants popularly used in Taiwan. Int J Appl Sci Eng 2005;3:195-202.

4. Oviasogie PO, Okoro D, Ndiokwere CL. Determination of total phenolic amounts of some edible fruits and vegetables. Afr J Biotechnol 2009;8:2819-20.

5. Vidhan J, Ara DM, John RP. Anthocyanins and polyphenol oxidase from dried arils of pomegranate (Punica granatum L.). J Food Chem 2010;118:11-6.

6. Marja PK, Anu IH, Heikki JV, Jussi PR, Kalevi P, Tytti SK, et al. Antioxidant activity of plant extracts containing phenolic compounds. J Agric Food Chem 1999;47:3954-62.

7. Namjooyan F, Azemi ME, Rahmanian VR. Investigation of antioxidant activity and total phenolic content of various fractions of aerial parts of Pimpinella barbata (DC) bioss. Jundishapur. J Nat Pharm Prod 2010;5:1-5.

8. Vinay RP, Prakash RP, Sushil SK. Antioxidant activity of some selected medicinal plants in western region of India. Adv Boil Res 2010;4:23-6.

9. Sun J, Chu YF, Wu X, Liu RH. Antioxidant and antiproliferative activities of fruits. J Agric Food Chem 2010;50:7449-54.

10. Chu YF, Sun J, Wu X, Liu RH. Antioxidant and antiproliferative activities of vegetables. J Agric Food Chem 2002;50:6910-6.

11. Eberhardt MV, Lee CY, Liu RH. Antioxidant activity of fresh apples. Nature 2002;405:903-4.

12. Delanty N, Dichter MA. Antioxidant therapy in neurologic disease. Arch Neurol 2000;57:1265.

13. Naik GH, Priyadarsini KI, Naik DB, Gangabhagirathi R, Mohan H. Studies on the aqueous extract of Terminalia chebula as a potent antioxidant and a probable radioprotector. Photomed 2004;11:530-8.

14. Chattopadhyay RR, Bhattacharyya SK. Plant Review Terminalia chebula. Pharm Rev 2007;23:145-50.

15. Chintalapani S, Swathi MS, Mangamoori LN. Phytochemical screening and in vitro antioxidant activity of whole plant extracts of Sesuvium portulacastrum. Asian J Pharm Clin Res 2018;11:322-7.

16. Ohkawa H, Ohishi N, Yagi K. Assay for lipid peroxides in animal tissues by thiobarbituric acid reaction. Anal Biochem 1979;95:351-8.

17. Kuda T, Tsunekawa M, Goto H, Araki Y. Antioxidant properties of four edible algae harvested in the Noto Peninsula, Japan. J Food Comp Anal 2005; 18:625-33.

18. Tiwary AK, Puri M, Sharma D, Barrow CJ. Optimisation of novel method for the extraction of steviosides from Stevia rebaudiana leaves. Food Chem 2012;132:1113-20.

19. Bloknina O, Virolainen E, Fagerstedt KV. Antioxidants, oxidative damage and oxygen deprivation stress. Ann Bot (Lond.) 2003;91:179-94.

20. Wani SM, Jan N, Wani TA, Ahmad M, Masoodi FA, Gani A. Optimization of antioxidant activity and total polyphenols of dried apricot fruit extracts (Prunus armeniaca L.) using response surface methodology. J Saudi Soc Agric Sci 2017;16:119-26.

21. Sanchez-Moreno C. Methods used to evaluate the free radical scavenging activity in foods and biological systems. Food Sci Technol Int 2002;8:121-37.

22. Jiang YH, Jiang XL, Bao HQ. Antioxidant Synergistic Effect and Formulation Optimization of Several Common Natural Pigments. ICMSA; 2015. p. 506-10.

23. Dakshayini PN, Mahaboob BP. Phytochemical screening and in vitro antioxidant potential of Tribulus terrestris fruit and Mesua ferrea flower extracts: A comparative study. Int J Pharm Pharm Sci 2018;10:70-5.

24. Moukette BM, Moor VJ, Nya CP, Nanfack P, Nzufo FT, Kenfack MA, et al. Antioxidant and synergistic antidiabetic activities of a three-plant preparation used in cameroon folk medicine. Hindawi Int Sch Res Notices 2017;2017:1-7. 